\title{
ALTERNATIF PENINGKATAN KREATIVITAS MAHASISWA UNIVERSITAS TRIBHUWANA TUNGGADEWI MELALUI MEDIA POHON MATEMATIKA
}

\author{
Rudy Setiawan', Rio Febrianto Arifendi² \\ ${ }^{1,2}$ Fakultas Ilmu Pendidikan Universitas Tribhuwana Tunggadewi \\ rudiehabibi@gmail.com ${ }^{1}$
}

\begin{abstract}
ABSTRAK
Penelitian ini bertujuan (1) mendeskripsikan langkah-langkah pembelajaran dengan media pohon matematika, (2) mengetahui pengaruh penggunaan media pohon matematika terhadap hasil belajar matematika, (3) mengetahui pengaruh penggunaan media pohon matematika terhadap kreativitas mahasiswa, dan (4) mengetahui pendapat mahasiswa tentang pembelajaran matematika dengan media pohon matematika. Rancangan dalam penelitian ini merupakan The Static Group Comparison. Peneliti memberikan perlakuan pada kelompok eksperimen dengan pembelajaran menggunakan media pohon matematika. Sedangkan kelompok kontrol adalah kelompok yang belajar tanpa menggunakan media pohon matematika. Sebelum penelitian, diadakan tes kemampuan awal (pretes) untuk masing-masing kelompok. Setelah dikenai perlakuan yang berbeda, maka masing-masing kelompok diberikan postes. Hasil penelitian menunjukkan bahwa: (1) Implementasi pembelajaran dengan media pohon matematika terdiri dari: a) Tahap awal, yaitu penjelasan peraturan pohon matematika dan pembagian kelompok; b) Tahap inti, yaitu masing-masing kelompok bekerja sama dalam mengkonstruksi daun pohon matematika; dan c) Tahap akhir berupa presentasi oleh masing-masing kelompok dan membahas jawaban. (2) Hasil belajar matematika mahasiswa yang belajar dengan menggunakan media pohon matematika lebih tinggi daripada hasil belajar matematika mahasiswa dengan metode pembelajaran ekspositori. (3) Pembelajaran dengan pohon matematika memungkinkan mahasiswa untuk menyelesaikan masalah dengan bermacam-macam interpretasi, metode penyelesaian atau jawaban sehingga kreativitas mahasiswa dapat berkembang. (4) Pembelajaran dengan media pohon matematika disukai mahasiswa.
\end{abstract}

Kata kunci: kreativitas mahasiswa, pohon matematika

This study aims to (1) describe the steps of learning with mathematical tree media, (2) to know the influence of mathematical tree usage of mathematics learning result, (3) to know the influence of mathematical tree usage on student creativity, and (4) to know student opinion about mathematics learning with math tree media. The design in this study is The Static Group Comparison. The researcher gave treatment to the experimental group by learning using math tree media. While the control group is a group that learns without using math tree media. Prior to the study, pretesting tests were conducted for each group. After being subjected to different treatment, each group is given post test. The results showed that: (1) Implementation of learning with math tree media consists of: a) The initial stage, namely the explanation of mathematical tree rules and division of groups; b) The core stage, that is, each group works together in constructing the leaves of the math tree; and c) The final stage of the presentation by each group and discuss the answers. (2) The result of mathematics learning of students who studied by using math tree media is higher than the result of students' mathematics learning with expository learning method. (3) Learning with mathematical trees allows students to solve problems with various interpretations, methods of completion or answers so that student creativity can flourish. (4) Studying with mathematical tree media preferred by students.

Keywords: math tree, student creativity 


\section{PENDAHULUAN}

Dalam pembelajaran matematika masih terdapat kendala-kendala missalnya, pada tingkat Sekolah Menengah Pertama (SMP) pembelajaran cenderung text book oriented dan masih didominasi dengan pembelajaran yang terpusat pada guru. Pembelajaran yang terpusat pada guru mengakibatkan adanya siswa-siswa yang tidak memperhatikan penjelasan guru bahkan ramai sendiri. Disamping itu juga model pembelajaran yang digunakan guru masih cenderung konvensional.

Perkembangan IPTEK dan informasi diperlukan sumber daya yang memiliki keterampilan tinggi yang melibatkan pemikiran kritis, sistematis, logis, kreatif, dan kemampuan bekerjasama yang efektif. Cara berpikir tersebut dapat dikembangkan melalui pendidikan matematika. Matematika merupakan salah satu pilar yang digunakan untuk memperkuat penalaran mahasiswa. Namun dalam proses belajar mengajar matematika, kebanyakan pengajar matematika mengajarkan prosedur tanpa menjelaskan mengapa prosedur tersebut digunakan. Hal ini mengakibatkan banyak mahasiswa yang kurang kreatif (Subanji, 2006).

Guna mengatasi permasalahan tersebut, maka perlu adanya suatu pendekatan dalam pembelajaran matematika sehingga dapat membantu mengembangkan kreativitas mahasiswa. . Dalam pembelajaran matematika, pengajuan masalah (problem posing) menempati posisi yang strategis. Pengajuan masalah merupakan tugas kegiatan yang mengarah kepada sikap kritis dan kreatif. Selain problem posing, pembelajaran matematika dengan pendekatan open ended juga bermanfaat dalam meningkatkan cara berpikir mahasiswa. Pembelajaran dengan pendekatan open ended dapat memberikan keleluasaan kepada mahasiswa untuk berpikir secara aktif dan kreatif dalam menyelesaikan suatu permasalahan (Suherman, 2003).

Berdasarkan uraian di atas, peneliti berusaha memadukan pendekatan problem posing dan open ended dalam pembelajaran matematika melalui media pohon matematika. Pohon matematika adalah gambar pohon yang digunakan dalam pembelajaran matematika. Pohon matematika terdiri dari batang yang merupakan materi utama dalam matematika, ranting yang berisi jawaban dari 
suatu permasalahan matematika, dan daun yang berisi masalah-masalah dari jawaban yang terdapat pada ranting atau sebaliknya.

Belajar merupakan proses perubahan tingkah laku individu yang relatif tetap sebagai hasil dari pengalaman, sedangkan pembelajaran merupakan upaya penataan lingkungan yang memberi nuansa agar program belajar tumbuh dan berkembang secara optimal (Suherman 2003). Pembelajaran secara bermakna (meaningful learning) adalah suatu cara mengajar yang lebih mengutamakan proses terbentuknya suatu konsep daripada menghafalkan konsep yang sudah jadi. Konsep-konsep dalam matematika tidak diajarkan melalui definisi, melainkan melalui contoh-contoh yang relevan dengan melibatkan konsep tertentu yang sudah terbentuk dalam pikiran siswa (Askury 2007). Pembelajaran yang baik adalah pembeljaran yang dapat memacu kreativitas siswa, Hurlock (1999) menyebutkan "kreativitas menekankan pembuatan sesuatu yang baru dan berbeda; kreativitas adalah kemampuan seseorang untuk menghasilkan komposisi, produk atau gagasan apa saja yang pada dasarnya baru dan sebelumnya tidak dikenal pembuatannya.

Tujuan dari penelitian ini adalah untuk mendeskripsikan langkah-langkah pembelajaran dengan media pohon matematika, mengetahui pengaruh penggunaan media pohon matematika terhadap hasil belajar matematika, mengetahui pengaruh penggunaan media pohon matematika terhadap kreativitas mahasiswa, dan mengetahui pendapat mahasiswa tentang pembelajaran matematika dengan media pohon matematika dalam pokok bahasan persamaan garis. Pembelajaran dengan media pohon matematika ini diharapkan dapat meningkatkan minat mahasiswa terhadap matematika sehingga hasil belajar matematika mahasiswa, khususnya pada materi persamaan garis, juga akan meningkat.

\section{METODE PENELITIAN}

Jenis penelitian yang dilakukan adalah penelitian eksperimental sungguhan (True Experimental Research). Dalam penelitian ini peneliti memberikan perlakuan pada kelompok eksperimen dengan mengajarkan materi persamaan garis lurus menggunakan media pohon matematika. Sedangkan 


\section{Rudy Setiawan', Rio Febrianto Arifendi ${ }^{2}$}

kelompok kontrol adalah kelompok yang melakukan pembelajaran tidak menggunakan media pohon matematika. Populasi dalam penelitian ini adalah seluruh mahasiswa Tribhuwana Tunggadewi. Sampel penelitian adalah mahasiswa Akuntansi semester 1 kelas D dan kelas E periode semester genap tahun akademik 2016/ 2017.

Instrumen perlakuan yang digunakan dalam penelitian ini adalah berupa media pohon matematika. Pohon matematika adalah media pembelajaran yang diwujudkan dengan gambar pohon. Pohon terdiri dari batang, ranting, dan daun. Teknik analisis data yang digunakan dalam penelitian ini adalah: (1) uji normalitas data skor tes hasil belajar matematika mahasiswa dengan rumus $X^{2}=\sum \frac{\left(E_{i}-O_{i}\right)^{2}}{E_{i}}$, (2) uji homogenitas data skor tes hasil belajar matematika mahasiswa $F=\frac{\text { varians terbesar }}{\text { varians terkecil }}$, (3) uji perbedaan dua rata-rata (uji-t), dan (4) uji chi-kuadrat hasil angket sikap mahasiswa terhadap pembelajaran dengan media pohon matematika.

\section{HASIL PENELITIAN DAN PEMBAHASAN}

1. Implementasi Pembelajaran Matematika dengan Pohon Matematika

Pohon matematika merupakan media pembelajaran yang diwujudkan berdasarkan gambar pohon. Pohon matematika terdiri dari bagian batang, ranting, dan daun. Batang berperan sebagai materi utama dalam matematika, ranting berisi jawaban, dan daun berisi masalah-masalah dari jawaban yang terdapat pada ranting. Pohon matematika juga bisa terdiri dari batang yang merupakan materi utama atau pokok bahasan dalam matematika, ranting yang berisi permasalahanpermasalahan matematika, dan daun berisi jawaban-jawaban dari permasalahan yang terdapat pada ranting.

Pembelajaran dengan menggunakan pohon matematika secara berkelompok juga dapat dilakukan dengan cara kompetisi antar kelompok. Dosen memberikan pohon sebagai materi utamanya dan ranting yang berisi jawabanjawaban dari permasalahan matematika. Sedangkan daun-daunnya berisi masalahmasalah yang harus dilengkapi oleh tiap kelompok. Penyelesaian oleh masing- 
masing kelompok harus cepat dan tepat karena harus bersaing dengan kelompok yang lain. Kelompok dapat melakukan diskusi dan kerjasama antar anggota dalam mengkonstruksi daun-daun pada pohon matematika. Mahasiswa berpartisipasi dalam kelompoknya masing-masing dan saling bertukar pendapat. Setiap kelompok menyelesaikan permasalahan sesuai dengan pengetahuan yang dimiliki. Dosen berperan sebagai fasilitator dan motivator yang mengarahkan dan mengawasi mahasiswa.



\section{Media pohon matematika yang dibuat mahasiswa}

2. Pengaruh Penggunaan Pohon Matematika terhadap Hasil Belajar Mahasiswa

Pengaruh penggunaan Pohon Matematika terhadap pembelajaran dapat dilihat berdasarkan analisis statistik data penelitian. Data tersebut berupa nilai pretes dan postes mahasiswa. Berdasarkan analisis data yang telah dilakukan maka diperoleh bahwa "hasil belajar matematika mahasiswa Universitas Tribhuwana Tunggadewi yang menggunakan media pohon matematika lebih tinggi daripada hasil belajar mahasiswa dengan metode ekspositori.

3. Pengaruh Pembelajaran dengan Pohon Matematika terhadap Kreativitas Mahasiswa

Pembelajaran dengan pohon matematika mendorong mahasiswa untuk menemukan berbagai jawaban dari suatu masalah yang diberikan. Temuan penelitian yang diperoleh berkaitan dengan kreativitas mahasiswa adalah sebagai berikut.

a. Mahasiswa menyelesaikan masalah dengan bermacam-macam interpretasi dan jawaban masalah 


\section{Rudy Setiawan', Rio Febrianto Arifendi ${ }^{2}$}

b. Mahasiswa menyelesaikan masalah dengan bermacam-macam metode penyelesaian

c. Mahasiswa membuat banyak masalah yang harus dipecahkan

d. Mahasiswa mendiskusikan berbagai metode penyelesaian

e. Pendapat Mahasiswa tentang Pembelajaran dengan Pohon Matematika

Pembelajaran dengan media pohon matematika membuat suasana pembelajaran matematika mengasyikkan dan tidak menakutkan. Jadi kesimpulan yang dapat ditarik adalah pembelajaran dengan media pohon matematika disukai mahasiswa.

\section{SIMPULAN}

1. Langkah-langkah implementasi pembelajaran dengan media pohon matematika terdiri dari: a) Tahap awal, yaitu dosen menjelaskan peraturan pohon matematika dan membagi kelas menjadi beberapa kelompok; b) Tahap inti, yaitu masing-masing kelompok bekerja sama dalam mengkonstruksi daun pohon matematika; dan c) Tahap akhir berupa presentasi oleh masing-masing kelompok dan membahas jawaban.

2. Hasil belajar matematika mahasiswa yang belajar dengan menggunakan media pohon matematika lebih tinggi daripada hasil belajar matematika mahasiswa metode pembelajaran ekspositori.

3. Pembelajaran dengan pohon matematika memungkinkan mahasiswa untuk menyelesaikan masalah dengan bermacam-macam interpretasi, metode penyelesaian atau jawaban masalah sehingga kreativitas mahasiswa dapat berkembang.

4. Berdasarkan hasil angket diperoleh rata-rata keseluruhan adalah $85,8 \%$. Mahasiswa tertarik dan menyukai pembelajaran dengan media pohon matematika.

\section{DAFTAR PUSTAKA}

Askury \& Subanji. (2007). Pengembangan Kompetensi Mahasiswa Materi Matematika Sekolah melalui Pembelajaran CRL dalam Rangka Mempersiapkan Praktek Pembelajaran di Kelas, Malang, Universitas Negeri Malang.

Hurlock, E. B. (1999). Psikologi Perkembangan: Suatu Pendekatan Sepanjang Ruang. Kehidupan. Edisi 5. Jakarta: Erlangga. 
Pehkonen, Errki. (2007). The State of Art in Mathematical Creativity. http://www.fiz.karlsruhe.de/fiz/publications/zdm ZDM Volum 29 (June 2007) Number 3. Electronic Edition ISSN 1615-679X.

Shimada. (2007). The Significance of an Open-Ended Approach, Reston, The National Council of Teacher Mathematics.

Silver. (2006). 'An Analysis of Aritmetic Problem Posing by Middle School Students', Journal for Research in Mathematics Education, vol. 27, no. 5, pp. 521-539.

Silver, Edward A. (2007). Fostering Creativity through Instruction Rich in Mathematical Problem Solving and Thinking in Problem Posing. http://www.fiz.karlsruhe.de/fiz/publications/zdm ZDM Volum 29 (June 2007) Number 3. Electronic Edition ISSN 1615-679X.

Siswono, Tatag Yuli Eko. (2006). Pengembangan Kriteria Tingkat Berpikir Kreatif Siswa dalam Matematika, Malang, Universitas Negeri Malang.

Subanji. (2006a). 'Berpikir Pseudo Penalaran Kovariasi dalam Mengkonstruksi Grafik Fungsi Kejadian Dinamik: Sebuah Analisis berdasarkan Kerangka Kerja VL2P dan Implikasinya pada Pembelajaran Matematika', Jurnal Ilmu Pendidikan, vol. 13, no. 1, pp.1

Subanji. (2006b). Pohon Matematika sebagai Alternatif Pembelajaran yang Kreatif. Makalah disajikan dalam Seminar Pelatihan Pembelajaran Kreatif tanggal 12 September 2006 di Pekanbaru.

Suherman, Erman. (2003). Evaluasi Pembelajaran Matematika. Bandung: JIC 